\title{
USING A DISCOURSE ADVERB TO CORRECT EXPECTATIONS: AN ANALYSIS OF MAK IN IRAQW
}

\author{
Amy Catling \& Maarten Mous \\ Leiden University
}

\begin{abstract}
The discourse verbal adverb mak was initially defined as both indicating stance and having the pragmatic function of hedging. In a further analysis using a corpus of Iraqw literature, this paper shows the function of the verbal adverb in Iraqw storytelling and proposes that mak is not related to stance. Instead, it was found that the verbal adverb acts at the discourse level highlighting an important aspect of a story, by organising contrasting information. In doing this, an Iraqw narrator has the ability to prevent audiences from making conclusions about a situation, by using mak to alert that more information is yet to come. This thorough analysis includes a comparison to five verbal adverbs that mak was initially grouped with (tsuwa, tó, lák, ák and alge), provides further insight into the functions of verbal adverbs, and a deeper understanding into the possible styles of storytelling from around the world.
\end{abstract}

Keywords: adverb, discourse, Iraqw, Cushitic, Tanzania, expectation management, verbal adverb, narrative structure

\section{Introduction}

The Iraqw adverb mák is one of those enigmatic markers that can be easily left out from a sentence without changing its content or rendering it ungrammatical. Such markers are usually left with a basic analysis as they are primarily pragmatic in nature. The adverb mak was initially glossed as 'somewhat' as a crude first approximation (Mous et al. 2002). This gloss suggests it indicates stance and in particular, indicates a hedging function (Fraser 1996). However, after a more careful analysis using a much larger dataset, we show that mak does not fit any of the suggested subcategories of stance adverbs.

Iraqw is a Southern Cushitic language spoken by approximately half a million people in Northern Tanzania. The data used for this research are primarily from several collections of folktales (Berger \& Kießling 1998, Wada Shohei 1976, Mous, Sanka \& Hhao (ed.) 2017, Hhao (ed.) to appear) which total to around 125 folktales and over 100,000 words. ${ }^{1}$ Our decision to focus on narrative stories was due to the availability of a large dataset of this speech genre created from previous research. The advantage of using narratives to research this type of adverb is that the relevant context is provided in the story. Narratives also constitute a coherent text that provides options to discover functions in the domain of information structure and cohesion in text or

\footnotetext{
${ }^{1}$ These texts were checked and digitised in the Iraqw Text and Society project sponsored by the Faculty of Humanities of Leiden University and the research team consisting of Sandra Bleeker, Amy Catling, Maarten Mous and Lea Zuyderhoudt worked closely with Basilisa Hhao in Kwermusl, Tanzania whose command of her mother tongue and excellent analytical skills contributed greatly to our findings; we are very grateful.
} 
discourse. The other literary genres for which we have considerable amounts of data, such as songs, oral poetry and riddles rarely contain mak nor any of the other verbal adverbs. These genres are less concerned with cohesion of content (songs) or are too short to display information management or express text coherence (riddles). Iraqw songs refer to historic events but do not recount them. Iraqw oral poetry is adhortative in nature and the power of words tends not to be modified by verbal adverbs. More information on Iraqw oral literature can be found on the Verba Africana website (Mous, Catling \& Bleeker 2018). More information on Iraqw grammar is available in Mous (1993). Verbal adverbs constitute a closed word category in Iraqw; which differ from sentential adverbs of place and time. Verbal adverbs can occur between the compulsory independent inflectional element termed selector and the verb. This compulsory inflectional element contains a subject clitic and sentence type information (dependent/independent clause) and additionally tense/aspect, object pronouns, mood (questioning, conditional, concessive, prohibitive) and directionality (ventive) can be expressed in the selector. There are clear restrictions and related syntactic behaviour of what can occur between the selector and the verb, and sentential adverbs of place and time cannot occur in this position. In (1), the verbal adverb baló is placed after the selector $a$ and before the verb tlawaká, and in (2), the verbal adverb hhó is placed after the copula $a$ in the nominal clause. ${ }^{2}$ Verbal adverbs may occur outside the verbal complex, in particular after the verb, but only if followed by the resumptive pronoun alé, as in (3).

\begin{tabular}{|c|c|c|c|}
\hline aníng & $\mathrm{a}$ & baló & tlaw-a-ká \\
\hline $1 \mathrm{SG}$ & $1 / 2$ & ever & go:1SG-PRED-NEG \\
\hline \multicolumn{4}{|c|}{ 'I'll never go.' } \\
\hline \multicolumn{2}{|l|}{ gadá } & $\mathrm{a}$ & hhóo \\
\hline \multicolumn{2}{|c|}{ thing:F:DEM } & $\mathrm{COP}$ & for.sure lie \\
\hline
\end{tabular}

$\begin{array}{lllll}\text { aníng } & \text { a } & \text { tlaw-a-ká } & \text { baló } & \text { alé } \\ \text { 1SG } 1 / 2 & \text { go:1SG-PRED-NEG } & \text { ever } & \text { RESPRO } \\ \text { 'I'll never go.' } & & & \end{array}$

Verbal adverbs typically express modification of the core of the predication while sentential adverbs give the background of the sentence, like 'once upon a time' in (4). Sentential adverbs are often derived from nouns, especially since a number of them are analysable as noun plus a suffix $(-o)$ to mark it as adjunct, as is the case of bálgeerawo in (4) (Mous and Qorro 2010). While sentential adverbs provide background to the content of the clause, verbal adverbs modify the interpretation of the event, and in the case of mak link the interpretation to new information that is still to come, hence operating at discourse level.

\footnotetext{
${ }^{2}$ The Iraqw orthography is used in this paper: / is a voiced pharyngeal fricative with creaky voice, $h h$ is a voiceless pharyngeal fricative, ' is a glottal stop (not written but present word initially and between different vowels, thus $a i$ is in fact $\left.a^{\prime} i\right), s l$ is a voiceless lateral fricative, $t l$ and $t s$ are ejective affricates, the former with lateral release, $n g$ is a velar nasal word-initially and word-finally and followed by a voiced velar stop between vowels. Double vowels are long; (high) tone is only being marked on the second vowel symbol. Low tone is left unmarked.
} 
(4)
bálgeeraawo
ta kaahi:
day:of:front:BGND
3IMPS say:3M
'Once upon a time, they say:...'

\section{Analysis of $m a k$}

This section consists of a thorough analysis of the verbal adverb mak. Our analysis includes an updated definition in the meaning and function of the adverb, followed by a consideration of the different contexts mak can occur. In particular, we pay attention to the affirmative, questions, dialogue and its use in negation.

The methodology of our analysis included a search for all instances of mak that occurred within a digital corpus of Iraqw narrative stories. The corpus primarily includes folktales from past research (Berger \& Kießling 1998, Wada Shohei 1976, Mous, Sanka \& Hhao (ed.) 2017, Hhao (ed.) to appear), and it is planned for the corpus to later become openly accessible for other researchers. Each instance of mak that was found was summarised; noting the placement of the word and what impact it had on the utterance. A comparison of all uses of mak was conducted, and this was analysed against the use of other adverbs that mak was grouped with by Mous (2018). All instances featured in our analysis were cross-checked and intensively discussed with a first language speaker of Iraqw to ensure our results accurately reflected the correct use of the adverb in each case. From this descriptive analysis, a conclusion was made about the meaning and purpose of mak within Iraqw.

2.1 The function of mak. Mak occurs 94 times in our corpus, which is at least 20 occurrences more than any other adverb analysed in this article. Mak has no particular lexical meaning but is consistent in its function. In all examples for our database, mak indicates that there will be an contrast in the next clause. This device appears to alert the reader to pay attention to the current events happening within the story, to highlight the contrast that is about to occur. This contrast can either oppose what is implied to happen next in the narrative $(5,6)$, or explicitly oppose what has just been stated $(7$, 8 ). These two possibilities will be described in further detail below.

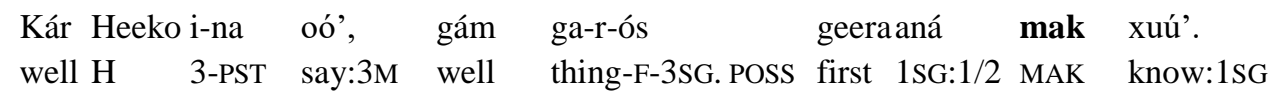

$\begin{array}{llll}\text { A } & \text { mak } & \text { di/itá } & \text { waasla. } \\ \text { COP } & \text { MAK } & \text { fat:F1:CON } & \text { python }\end{array}$

'They said, how does that stomach leave her being killed? Then Heeko said, well I know the medicine, but it is oil from the python.' (Mous et al. 2017: story of Mtunduri)

$\begin{array}{lllll}\text { xwayliité-r-'eé' } & \text { a } & \text { mak } & \text { artáwá } & \text { slaá', } \\ \text { parents-F-1SG.POSS } & 1 / 2 & \text { MAK } & \text { seeing:ABL } & \text { want:1SG }\end{array}$

asma án daqaari'iimár yaariit a ló’wa koóm

because 1SG richness:F:CON big:FO.F very have:1SG

'I want to see my parents, because I am very rich.' (Wada 1976: Story of Simbooya)

In example (5), mak opposes implied information about what will happen next. Heeko states that he knows the medicine that will heal the mother's stomach. This statement implies that it is possible to 
heal the mother, which is what we would expect to happen next. However, the next clause shows that this may not be possible, as the medicine is from a python. The use of mak alerts us to the contrast before the audience is given any more information. In this example, mak is used twice. Both uses of mak link together the two clauses with contrasting information and is used twice as they are in different sentences.

The same pattern occurs in example (6). In this example, Simbooya wants to see his parents. This implies Simbooya will then go to see his parents. However, the next clause states that his parents live far away and are difficult to find; implying that he will be unable to see them. Mak is inserted in the first clause, marking the upcoming contrast that follows in the next clause. In this case, there is only one use of mak, as the contrast is within two clauses in the same sentence.

In other uses of mak, the contrast is not about what is expected to happen next in the narrative but opposes what has just been explicitly stated. This can be seen in the two examples below.

$$
\begin{array}{lllll}
\text { gitlaa-qá' } & \text { baré } & \text { aáng } & \text { a mak } & \text { narkutamo. } \\
\text { man.M-DEM3 } & \text { SURPIRSE } & \text { before } & \text { COP MAK } & \text { poor.man }
\end{array}
$$

$\begin{array}{llllll}\text { Hikwaa-qá' dír } & \text { ngi-wa } & \text { sláy a } & \text { diimá. } \\ \text { cattle.P-DEM3 } & \text { place:F:CON } & \text { O.3:O.P-BGND } & \text { get:3M } & \text { COP } & \text { where }\end{array}$

'(That man used to be poor.) Where did he get that cattle?'

(Mous et al. 2017: story of Geesó Duqang)

$$
\begin{array}{llllll}
\text { ni/i } & \text { ni-ri } & \text { oo-iyé', } & \text { “A } & \text { mak } & \text { aayíhee?" } \\
\text { children } & \text { VENT-CSEC } & \text { say-3P:PRF } & \text { COP } & \text { MAK } & \text { mother:PRED:Q }
\end{array}
$$

Aluuwo ni/i nay ooiné' do' nguri gweer-iyé', afterwards children VENT:CSEC say:IPFV:3P:PRF house O.3:O.M:CSEC open-3P:PRF "The children said: "Is that mother? Then the children answered the door and opened.", (Wada 1976: story of Baha, Saaramadé nee Ookwa/ángw)

In example (7) a character states that a man was poor. Immediately afterwards, they state that he has a lot of cattle, meaning that he is rich. Mak is used in the first clause, marking the upcoming contrast. The same pattern is found in example (8). The children expect to open the door to their mother, and mak marks the contrast that the person at the door is in fact the hyena.

We have used the term contrast here, but it is important to take into account that mak is different from contrastive markers in many other languages due to the fact that it does not negate the first element. It does not assert that the statement of the first element is not valid. Izutsu (2008) discusses contrastive markers of two main types, sino / sondern and pero / aber; these markers of contrast entail a correction of the replacive kind (i.e. instead, rather). Mak corrects by providing further information but not necessarily denying the first element. In this respect it is comparable to Gawwada $=a k k$ Tosco (2010:335) in its derived second use. "In this use, =kka follows a new element and operates as a focus marker. At the same time, the newly introduced element sets the scene for the next clause, which runs against the expectations created by the first. By this operation of scene-setting, the first clause becomes topical at the discourse level: still, =kka marks it qua new and focal." In this explanation, Tosco provides the example of a riddle: "look here: I got four legs, and still I cannot walk" in which the answer is "a stool". 
An interesting point about (8) is that mak is used within direct speech of a character, which may suggest that the character already thinks that it is not their mother at the door (for more on this point, see section Addressees). This is not clear for all instances of mak in direct speech, but whether mak tells us about the perspective of the character or not, the function of the adverb is consistent in all our examples.

2.2 Repetition and scope of mak. For mak to fulfil its purpose in highlighting a contrast, two components are required. A first clause is used to describe a situation, which may or may not be new information to the audience. A second clause is then required to detail additional information, which marks an unexpected contrast from what the audience was told in the first clause. This pattern occurs in all 94 cases of mak within our corpus. Mak always appears within the first clause, and is used to point towards an upcoming contrast, never to a contrast with something previously stated. Occasionally, there is repetition of mak when describing one contrast. Although in these cases the structure appears to be more complex, the adverb still appears to be forward-facing. This can be seen in examples (11) and (12). Example (11) is the continuation of example (5) where we have already seen a repetition of mak. The boys have asked the mother where to find the python and she answers using mak again.

$\begin{array}{llllllll}\text { Aama } & \text { i-na ó, aná } & \text { mak } & \text { dii } & \text { xuú', ala a qitlâ'a, } \\ \text { g.mother } & \text { 3-PST say:3F1SG:PST } & \text { MAK } & \text { place know:1SG but } & \text { COP man:PRED:Q }\end{array}$

$\begin{array}{lll}\text { ga-dá-dá' ka } & \text { ló’wa úr } \\ \text { thing.F-DEM4-DEM4 O3:IMPS:O.F very big }\end{array}$

$\begin{array}{llllll}\text { Bará } & \text { guruú } & \text { bohoongo } & \text { sleeme } & \text { i } & \text { fak-a-ká, } \\ \text { in:CON } & \text { inside:CON } & \text { pit:PRED } & \text { also } & 3 & \text { finish-PRED-NEG }\end{array}$

yaamukae i fak-a-ká.

area.P:DEM1.P:PRED 3 finish-PRED-NEG

'Mother said: "I know the place, but is it [a job for] a man? That thing is very big. Inside a pit as well and one without end; there is no limit to its area." (Mous et al. 2017: Story of Mtunduri)

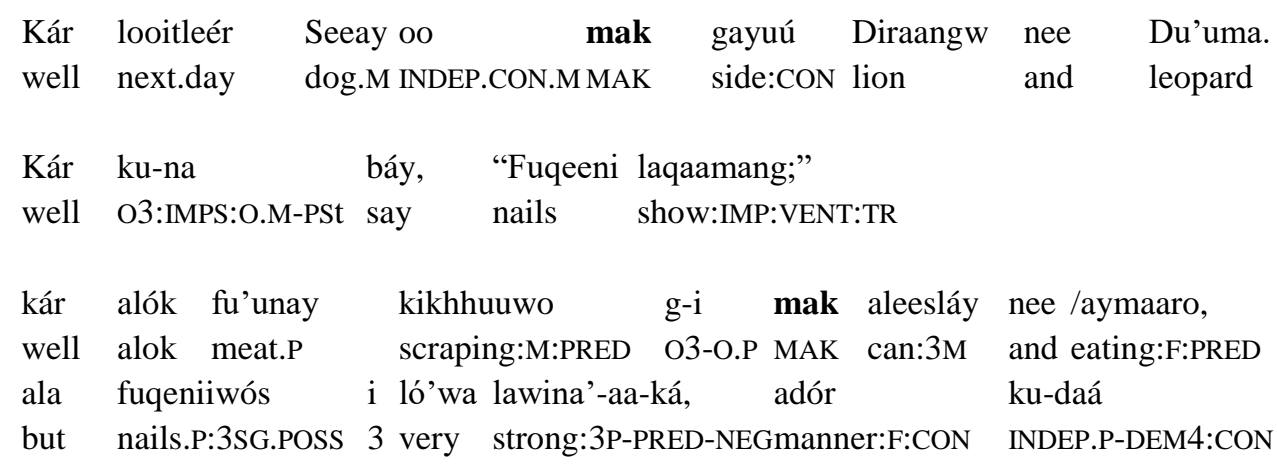


$\begin{array}{llll}\text { Diraangw } & \text { nee } & \text { Du'umuúwá } & \text { alé. } \\ \text { lion } & \text { and } & \text { leopard:M:ABL } & \text { RESPRO }\end{array}$

'Then Dog used to be in the group of Lion and Leopard. He was told: "Show me your nails." Well he can scrape and eat meat with them but his nails are not very strong, not like those of Lion and Leopard.' (Wada 1976: Story of Seembásl nee Garaangw)

By considering (5) and (11) as one extract, there are 3 elements of the story describing the whereabouts of the antidote that the character is looking for. In each element describing its location, mak is used repeatedly. The first instance of mak is within a clause that states the mother knows where the location of the antidote; the second is within a clause explaining the antidote is the oil of the python, and the third is in another clause stating she knows the location of the python. In each clause that mak is present in, the narrator is building up information, and consistently highlights that crucial information is about to come. The repetition of mak within this context can add rich detail to the information the storyteller is providing by pointing forwards to an upcoming contrast.

The same pattern of repetition occurs in (12). Mak is first used when it is stated that the dog is the same as the lion and the leopard. More detail is added to this idea in the clause containing the second mak, where it states that the dog can eat meat in the same way as these two animals. The upcoming contrast that is expected after mak occurs immediately after this second use of mak, in which we are told that the nails of the dog are unlike those of the lion and leopard, as they are not strong.

When mak is used multiple times, the reveal of the crucial contrast is delayed as the audience is told more about the described situation. Marking each extra detail given with mak is not a requirement of the adverb, but entirely the choice of the storyteller. Example (18) (see Negation) is from a story in which a boy is given one impossible task after another. In one of the episodes about an impossible task, the storyteller has used mak three times. However, mak is not used once in a parallel episode about a similar impossible task.

Regardless of whether mak is used once or multiple times, in all cases it is a forward-facing adverb. Its syntactic positioning has been discussed (see Introduction), and due to the function of the adverb, it is never used to indicate that the clause it is placed in contains crucial information for the story, but only that it is about to come. The second clause containing the contrast does not need to be the immediate next clause. The distance to the correction is in all attested instances, however, well within the limit of six clauses that Myhill and Xing (1996:319) use as operational maximal distance for considering two elements for potential contrast as being part of a list.

2.3 Addressees. Both the audience to a story and the characters within it can be the intended addressees of mak. This is shown in the use of mak by the narrator of a story to the audience (13), in an internal dialogue for one character (14) and within direct speech for multiple characters (15).

$\begin{array}{llllll}\text { (13) Kár } & \begin{array}{l}\text { tookaaro } \\ \text { well }\end{array} & \begin{array}{l}\text { yâ, } \\ \text { BREAK }\end{array} & \begin{array}{l}\text { kwa/aangw ís } \\ \text { hare }\end{array} & \begin{array}{l}\text { nee } \\ \text { with }\end{array} & \begin{array}{l}\text { konkomo, } \\ \text { cock }\end{array} \\ \begin{array}{l}\text { Kwa/aangw } \\ \text { hare }\end{array} & \begin{array}{l}\text { ís a } \\ \text { 3SG COP }\end{array} & \text { MAK } & \begin{array}{l}\text { al/aymusmo. } \\ \text { deceiver }\end{array} \\ \text { 'The hare, he is a deceiver.' (Mous et al.2017: Story of Kwa/aangw nee Konkoomo) }\end{array}$


(14)

$\begin{array}{lllll}\text { Daangw } & \text { daee-r-o } & \text { i-na } & \text { oó’, } & \text { “Gám geera laarí } \\ \text { elephant } & \text { fearing-F-PRED } & \text { 3-PST } & \text { say:3M } & \text { well first today }\end{array}$

ngi-n qo mak huúw.";

O3:O.F-EXPEC EMPH MAK bring:1SG

'Elephant said with fear: "Well first let me bring her today.' (Wada 1976: Story 10 of

Lehhtuusér tlaaqati)
Tundu
mak
hhohhó' haywa'. ala dír
/Arí a eer-a'-aa-ká.
IMPS:O2PL mak nice:PL children but at A. O.F go:2-PL-PRED-NEG
'You are all beautiful in some respect, my children. But you don't reach /Ari.' (Berger \&
Kießling 1998)

Example (13) is an extract from the introduction to a story, in which the audience is told that although the hare usually deceives others, within this story the cockerel will beat him. This information is highlighted to give the audience greater understanding of the characters and what is to be expected in this story. The same structure is found in (15). Mak is used as one character speaks directly to other characters. The first sentence describes all the children as being beautiful, but the presence of mak indicates not all the information has been said, and the unexpected contrast arises in the following clause which states none of the children are as beautiful as /Ari.

Within the internalised direct speech example of (14), the use of mak gives additional information to the audience about what is about to happen; although the elephant brings his wife, the situation ends badly as his wife leaves with the hare. This contrast could not be predicted by the character - but as it is the character who introduces the situation using mak, this positioning of the adverb may suggest that the character has some knowledge that new information is about to occur. It cannot be confirmed in our dataset whether the use of mak in direct speech indicates doubt on the behalf of the speaker, but at the same time, this is an indication for the audience that a correction to this thought is going to appear soon. Example (15) has shown that mak can be intended to address other characters in a story, meaning that we cannot rule out the characters as intended addresses to the adverb, as well as the audience.

2.4 Negation. Although negation of mak is possible, only 4 straightforward occurrences were found out of the 94 instances of mak in our entire dataset. Example (16) was discussed with first language Iraqw speaker and author of one of the books within our corpus, Basilisa Hhao. We were informed that the example is only possible as more information follows within the sentence that is different from what has been said. This confirmation was consistent with our previous findings about the function of mak. In example (16), the logical way to complete this sentence would be to add the clause 'but they will be.' Similarly, in another constructed example (17), mak indicates that they will worry.

$$
\begin{array}{llcc}
\text { muu } & \text { ku } & \text { mak } & \text { /aa/aa-ii-ká } \\
\text { people } & \text { O3:IMPS:O.M } & \text { MAK } & \text { cry-3:PRED-NEG } \\
\text { 'People are not cried for.' (Hhao in press: Story of Gwaandé/) }
\end{array}
$$




\author{
i mak gurhaamut-ká \\ 3 MAK worry-NEG \\ 'They didn't worry at all. ' (Berger and Kiessling 1998: text of Sarwat)
}

The remaining negative examples in our dataset can be found below $(18,19)$. In (18), a boy wants to marry a girl but his soon to be in-laws set him impossible tasks to try and stop the marriage. Mak serves here to look ahead and confirm that nevertheless, the boy will succeed in the end. In (19), the hare insists that the dove should give him some of her children to eat, otherwise he will climb the tree and eat them all. When it comes to the last child, the dove refuses and the hare threatens to climb the tree - but he cannot. Mak here seems to mark the clue that the hare cannot climb the tree, which the audience already knows but the dove only finds out after being told by the kite. For the hare, the fact that the dove now knows he cannot climb the tree after being told by the kite is the surprising, corrected information that is presented in the sentence following this one.

$$
\begin{array}{llll}
\text { ku } & \text { mák } & \text { haree-r-o } & \text { slaa-ii-ká } \\
\text { O3:IMPS:O.M } & \text { MAK } & \text { wife-F-PRED } & \text { want-3:PRED-NEG }
\end{array}
$$

'He is not wanted getting a wife.' (Mous et al. 2017: Story of Garma nee Dasi)

\begin{tabular}{|c|c|c|c|c|c|}
\hline $\begin{array}{l}\text { Hhooki } \\
\text { dove }\end{array}$ & $\begin{array}{ll}\text { laá } & \text { kaa } \\
\text { today } & \text { O3:0.F:PF }\end{array}$ & \multicolumn{3}{|c|}{ gurbuiîke } & \multirow[t]{2}{*}{$\begin{array}{l}\text { nee kuuraay. } \\
\text { by kite }\end{array}$} \\
\hline 'Wasn't & Oove informed by K & y?' ... & & & \\
\hline Laatí & tsa/amto & ga & qo & mak & baal-ii-ká. \\
\hline SURPRIS & climbing:F1:PRED & O3:O.F & EMPH & MAK & succeed-3:PRED-NEG \\
\hline
\end{tabular}

Negation may be syntactically possible with mak but the remarkably little usage of it may tell us about the way events are presented in an Iraqw story. The purpose of negation is to highlight what a situation is not. This may often take precedence over the purpose of mak, which highlights what information is important to know for the story. Starting with a positive sentence and using mak to lead to a sentence containing negation is more natural than the other way around. If an introductory sentence contains a negative form, that negation is asserted. To then announce that this asserted negative statement is incorrect by using mak is contradictory. It is better to use mak with positively formulated statements if the narrator is referring to a negative situation that turns out to be better than expected. It is not logically impossible to use mak in a sentence with negation; it is simply pragmatically odd.

As the use of mak is not required in any narrative, it is entirely the storyteller's choice whether it is used. Certain passages are concentrated in their use of mak and others lack it without any seemingly obvious reason. As for negation, the general lack of negative mak suggests that semantically it is preferable for the story not to negate mak, regardless of whether it is syntactically correct

or

not.

2.5 Mak in questions. In the section Addressees, example (10), we saw that mak can occur in questions. It is worth noting that in most instances where mak is used in what is formally a question, 
these are usually cases of inner speech by one of the characters, and this appears to mark doubt and scepticism on the behalf of the speaker as we saw above in (14). The questions in which mak are used are all yes/no questions. Yes/no questions in Iraqw are often leading rhetorical questions and evoke an expectation rather than making an assertion. The addressee has an expectation to one of these values (yes/no), but whatever that value is, mak warns that this expectation may not be valid; mak operated on the expectation evoked by the question and counteracts that expectation. When such a yes/no question with mak is inner speech and the addressee is in fact the speaker, it results in the expression of doubt and uncertainty of the speaker. This is detailed again below. In (20), a man who went herding sits on a rock that turns out to be extremely hot and questions:

$$
\begin{array}{lllll}
\text { laarí tlaa/a-r-í } & \text { gwa'ara } & \text { g-a mak } & \text { méera. } \\
\text { today rock-F-DEM1 } & \text { dying } & \text { O3-O.F MAK } & \text { leave:2:PRED:Q }
\end{array}
$$

"Does this rock really have to die today?" (Berger and Kießling 1998)

Similarly, in (21), the hyena wonders whether the antelope really ate her children as they agreed. Later in the story, as expected by the use of mak in this extract, we discover that she did not.

$$
\begin{aligned}
& \text { tlaaqati na/ay-w-ós g-w-a mak lági. } \\
& \text { antelope child-M-POSS.3SG O3-O.M-PRF MAK eat:3F:PRES:Q }
\end{aligned}
$$

"Did the antelope really eat her child?"

In addition, mak occurred 4 times in leading questions that contain both negation and questioning, as found in example (22). However functionally, these are not negating statements. The vomiting of the hyena in example (22) will happen, but after the hyena vomits all the meat that belongs to the elephants, they then kill him. This death, rather than vomiting, is the unexpected turn in the story.

$$
\begin{aligned}
& \text { Daawe i-ri ó', "Hhaawu i mak wa/ará } \\
& \text { elephants.F 3-CSEC say:3F hyena.F } 3 \text { MAK vomiting:CON } \\
& \text { aeer-aákê, kár i-wa lét } \quad \text { baraá yaee. } \\
& \text { go:IMPFV:3F-PRED:NEG:PRED:Q well 3-BNGD go.down:3F in:CON river } \\
& \begin{array}{llllll}
\text {... Háthhaawú } & \text { i } & \text { fu'unaá } & \text { wa/amiín. } & \text { Baraá } & \text { yaae. } \\
\ldots \text { niece } & 3 & \text { meat:P:CON } & \text { vomit:IMPFV:3F } & \text { in:CON } & \text { river }
\end{array} \\
& \text { Daangw ngiwa ár, ina buúhh, } \\
& \text { elephant DEP3-BGND see:3M 3-PAST be.angry:3M } \\
& \text { nee Háthhaawú g-a-ri daanda tlawaá/ ar guhhláy, } \\
& \text { and niece O3-O.F-CSEC back hit:3M by club } \\
& \text { g-a-ri muúx, g-a-ri gaás. } \\
& \text { O3-O.F-CSEC beat:3M O3-O.F-CSEC kill:3M }
\end{aligned}
$$

'Elephants said: "Hyena is going to vomit, isn't it?" when she went down to the river. ... 
[they saw] that the hyena [niece] vomited meat into the river. When Elephant saw that he was furious and clubbed the hyena on the back and beat and beat and killed it.' (Wada 1976: story 2)

The leading question in example (23) implies that what the children are saying is nonsense. However, the cow does sing and what the children say is in fact true. The insertion of mak corrects the message of the sentence; not any of the formal markers such as negation or questioning.

\begin{tabular}{|c|c|c|c|c|c|}
\hline $\begin{array}{ll}\text { Baabá i } & \text { kaahi, } \\
\text { father } 3 & \text { say:3M }\end{array}$ & $\begin{array}{l}\text { "Slér } \\
\text { cow:F:CON }\end{array}$ & $\begin{array}{l}\text { da'a'aat } \\
\text { singing }\end{array}$ & $\begin{array}{l}\mathrm{a} \\
\mathrm{COP}\end{array}$ & $\begin{array}{l}\text { ma'á? } \\
\text { what }\end{array}$ & \\
\hline laqaloo-r-í & kur-k-í & ga-r-ka & $g-a$ & mák & ó'ke." \\
\hline young.boys-F-DEM1 & year-M1-DEM1 & thing-F-INDF & O3-O.F & MAK & say:3F:NEG:PRED:Q \\
\hline
\end{tabular}

Leading questions with a questioned negation expect the answer "yes". Mak indicates that that expectation will turn to need to be modified.

Content questions are by definition not assertions and are therefore not modified by mak. Yes/no questions always have the option to be interpreted as a leading statement in Iraqw. Very often a negative statement is phrased as a non-negative question. Hence mak is possible with yes/no questions.

\section{The function of $m a k$ in relation to other adverbs}

Mak is one of a limited set of verbal adverbs that form a closed word category different in behaviour from sentential adverbs, as explained and demonstrated in the introduction. These verbal adverbs modify the verb and its dependents, from the inflectional element termed selector up to the verb. The elements that can occur within this core of the sentence are limited to case clitics, backgrounded objects or object pronouns representing fronted objects and verbal adverbs. The order of elements within this core of the sentence does not seem to be meaningful.

We have mentioned Gawwada's contrast marker $=k k a$ as being similar to $m a k$ which $=$ akk is characterised in terms of focus by Tosco (2010). Consider Lambrecht's definition of focus "the element of information whereby the presupposition and the assertion differ from each other. The focus is that portion of a proposition which cannot be taken for granted at the time of speech. It is the unpredictable or "pragmatically non-recoverable element in an utterance." (Lambrecht 1994:207: emphasis in the original). This sounds similar in a number of respects to our analysis of the function of mak as we are also dealing with a difference between presupposition (in the expectation on the development of the story) and assertion, and not taking something for granted. However, in our case, it is not about a portion of the proposition but rather the whole statement. Secondly, mak is not about "new" or unpredictable or unrecoverable information but looks instead ahead.

Actual linguistic markers may function in various meta-linguistic domains. For example, we analyse the marker mak as regulating narrative but we have also shown how this marker can express 'doubt' on the part of the speaker in yes/no question in inner speech, which is in the domain of stance. Tosco (2010:335) shows how the Gawwada marker for switch of topic $=k k a$ can serve to 
express counter-expectational in structures such as "I got four legs but I still cannot walk". The marker is attached to the four legs and indicates here that in what immediately follows something unexpected is expressed. This is reminiscent in some aspects of our analysis of mak: the indication of counter-expectation and the forward orientation of $=a k k$ in this use. A second property in common is that although the Gawwada =akk is attached to one constituent (unlike mak) it is similar in modifying the whole predication in Gawwada as being "new", in Iraqw as statement to be modified. This last fact is a major difference too because in Gawwada the truth value of the first predication remains valid or, at least, the validity of its contents is not addressed by the use of mak. The main purpose of our comparison with Gawwada is however to stress that language specific markers can function in several metalinguistic categories. The Gawwada switch-topic marker develops into focus and counter-expectational, and - in combination with a specificity marker - even into contrastive focus (Tosco 2010:337). The Iraqw verbal adverb mak is basically regulating narrative but in that it expresses counter-expectation for what follows, like Gawwada $=a k k$.

As a consequence, it is important to contrast mak to other Iraqw verb adverbs in the area of discourse management.

Adverbs that modify the predication often express the stance of the speaker or the subject. Various types of stance adverbials have been proposed such as epistemic, attitude and style stance with epistemic divided into doubt/certainty, actuality/reality, source/evidence, limitation, viewpoint or perspective and imprecision (Biber et al 1999 as quoted in Tseronis 2009). We have so far shown that mak does not express stance but instead is a part of the narrative structure. Although doubt does play a role in some sentences containing mak, this mostly occurs in (rhetorical) questions within the inner speech of characters. This potential element of doubt is due to the interplay of the fact that the responsibility is on the character rather than the narrator, and hence, this indicates the character predicts a different situation than the one in the sentence will turn out to be valid, showing questioning and doubt on the behalf of the character, modifying the expectations that a yes/no question evoke. While mak is in essence structuring narrative it can in certain constructions express doubt, the question arises how the other verbal adverbs in Iraqw express elements of stance and information management and they overlap and differ from mak.

Iraqw has 18 of such verbal adverbs with a variety of functions. The following table contains the full list of the closed category of verbal adverbs in Iraqw. 
Table 1: Iraqw closed category of verbal adverbs explained (modified from Mous 2018, based on Mous 1993)

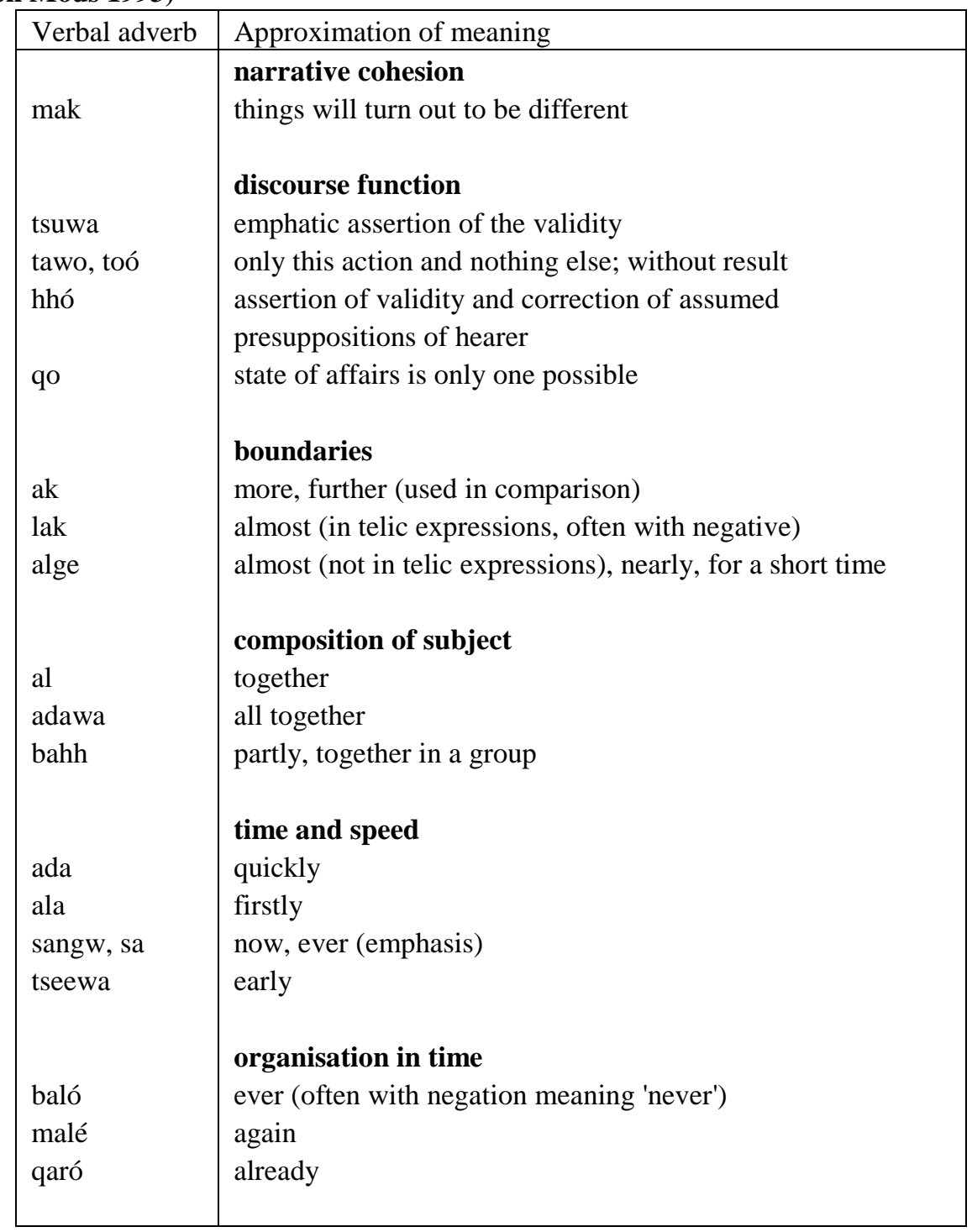

A number of these adverbs express aspects of how the event compares to universal time, such as with baló 'ever' and malé 'again', or the extension of the phase beyond point of speech as in qaró 'still'. Some adverbs refer to the beginning or the speed of an event, ala 'firstly', tseewa 'early', sangw 'now', ada 'quickly'.

We do not compare mak to verbal adverbs that are very different in functions to mak such as composition of subject, time and speed, and organisation in time. The closed paradigm of verbal adverbs clearly does not express one semantic category; rather they convey quite different functions in the pragmatic domain. There are some adverbs that seem to regulate expectations on the part of the interlocutors, such as tawo 'in vain, just (but also once)' and tsuwa 'for sure'. Since these are closest to the function of $m a k$, we analyse both below. Some adverbs are concerned with boundaries, 
such as lák 'almost', ák 'more (used in expression of comparison)', and algé 'almost.' We add comparison with the verbal adverbs related to boundaries for completeness.

The other two adverbs with discourse function, qo and hho have been dealt with elsewhere. The adverb qo asserts and selects the expressed event as the only valid one among all comparable events; it is often used with verbs of saying to remove any doubt (Elders and Mous 1991). While qo expresses assertion, it does not indicate evidentiality as such. However, other adverbs express certainty on the part of the speaker. For example, hhó indicates that the speaker has positive evidence and corrects any different ideas of other participants in the dialogue (Mous and Qorro 2008).

3.1 Tsuwa. The first adverb we will compare our analysis of mak to is tsuwa. While the dictionary suggests mak softens a statement by meaning 'somewhat,' it suggests that tsuwa strengthens it. The meaning of tsuwa given in the Iraqw dictionary (Mous et al. 2002) is 'for sure'. This function of asserting the validity of the message expressed in the clause as can be seen in (24). The cannibal utters this statement in despair when she has thrown a mother into the fire out of frustration that her children have escaped. The cannibal talks to herself aloud: "That nice meat of mine is absent. That nice meat of mine is tsuwa lost. The Swahili translation uses $t u$ 'only, just, exactly, simply, no more, merely, barely' (Johnson 1939:474) to render the meaning of tsuwa.
Fu'unay-'eé' kudá' hhohho' nay
tsuwa qwaar-iyé'.
meat.P-1SG.POSS P:DEM4 nice:P HITH:CSEC
TSUWA be.lost-3P:PF
'[That nice meat of mine is absent.] The good meat of mine is just lost.' (Hhao in press: Story of Aga)

The adverb tsuwa does not add any content to the statement. It does not refer to the presuppositions of any other participant in the story, nor of the audience. Presuppositions are here understood as pragmatic rather than semantic in nature and projected in the speaker and the hearer and not in the sentence following Stalnaker (1973). It asserts the validity of the statement. This clause is in fact a rephrasing of the preceding clause and the repetition in itself has the same function of emphatic assertion.

Kießling glossed the adverb with 'indeed' (Berger and Kießling 1998), expressing confirmation of a claimed fact. This function is clear in (25) from the Simbooya story (Nordbustad 1978 b) in which the messenger bird is carrying a spear that it claims to belong to the brother of Simbooya, to which he answers:

$$
\begin{array}{lllll}
\text { I-na } & \text { oó': } & \text { "A tsuwa ló', } & \text { lawala-síng ar } & \text { tsuwá } \\
\text { 3-PST } & \text { say:3M:PST } & \text { COP TSUWA truth } & \text { spear.F-DEM2 indep.F.CON } & \text { TSUWA }
\end{array}
$$

hhiyaa-eé'."

brother-1SG.POSS

'It is really true. This spear indeed belongs to my brother.' (Nordbustad 1978b)

Further down in the story, the same structure occurs about the pestle of which Simbooya reports:

$$
\begin{array}{lllllll}
\text { I-na } & \text { oó': } & \text { "Musuuw-í } & \text { a } & \text { tsuwa } & \text { kuduú } & \text { aamár } \\
\text { 3-PST } & \text { say:3M:PST } & \text { pestle.M-DEM1 } & \text { COP } & \text { tsuwa } & \text { M.DEM4:CON } & \text { mother:CON }
\end{array}
$$




doo-rén án naa tsaát ar dabaaeé' $\quad$ awa
house:M-1PL.POSS 1SG 1:PRF cut:1SG with hand:1SG.POSS INDEP.P.CON real
'He said: "This pestle is indeed the one of our house; I have cut it myself with own
hands."” (Nordbustad 1978b)

Simbooya acknowledges that this is indeed the pestle of home as he has cut it with his own hands. Simbooya may be relieved or even surprised that these items are from his former home but $t$ suwa does not by itself indicate correction of expectations. In the story, Simbooya is convinced that the messenger bird will succeed in bringing his parents to him. In these examples, tsuwa does not express expectation management; it simply confirms what the preceding sentence claims, that was uttered by the messenger bird.

In the following sentences, tsuwa is used for situations that are not in doubt by any of the participants in the story. In this passage, the animals are trying to find out what happened to the cat, the master of the house, referred to as 'mother'. The leopard denies vehemently to be involved in her disappearance:

$\begin{array}{llllll}\text { i-na } & \text { oó', } & \text { oryoó ala án } & \text { n-ay } & \text { tsuwa alúr } & \text { kí/a, } \\ \text { 3-PST } & \text { say:3M:PST } & \text { guys but } & \text { 1SG } & \text { HITH-CSEC } & \text { TSUWA behind:CON return:1SG:PRED:Q }\end{array}$

$\begin{array}{llllll}\text { n-ay } & \text { tsuwa aayí } & \text { laymár } & \text { áwa } & \text { baraá } & \text { do'. } \\ \text { HITH-CSEC } & \text { TSUwA mother } & \text { eating:CON } & \text { go:1SG:PRED:Q } & \text { inside:CON } & \text { house }\end{array}$

'He said: Hey, guys, should I really return from behind; I really went into the house to eat mother?' (Hhao in press: Story of makaay)

The verb in these clauses contains a predicative marker which is translated in Swahili as a question. Tsuwa is used here to indicate that the content of these clauses cannot be true. The questioning predicative marker together with the adverb tsuwa adds strong doubt or denial in the content of the clause. Tsuwa often occurs with a question and/or negative expression. Tsuwa, or its variant tsuwá, occurs 32 times in our corpus and in 12 of these, the verbs contain the question marker. Tsuwa can be used in a question as in (28), in which case doubt is casted on the outcome and the question is rhetorical - the validity of tsuwa is questioned. In this story, the elephant is asking himself and all animals present whether the hare will succeed in being allowed to marry the antelope when all others have been refused.

$$
\begin{array}{llll}
\text { laá looqaanamoo-qá' } & \text { g-a-n } & \text { tsuwa hayoóhi ? } \\
\text { today } & \text { worthless.person-DEM3 } & \text { O3-O.F-EXPEC } & \text { TSUWA take:PRED:3M:Q } \\
\text { 'Will that worthless thing (i.e. Hare) } & \text { really take her as wife?' (Wada 1976: Story 10) }
\end{array}
$$

Tsuwa can be both questioned and negated as it is in (29) from the famous story of the man-eating monster Ama Irmi, where the monster has eaten and taken over the role of the sister in the house and is being fed by her poor brother who does not enter the house because he thinks his sister is ill. In (29), Ama Irmi contemplates:

$$
\begin{aligned}
& \text { Kár ala garma ngi-wa xui a-qo án tsuwa } \\
& \text { kar but boy DEP.O3-BGND know:3:DEP COP-EMPH 1SG TSUWA }
\end{aligned}
$$


deenaa-r-okéhe?

sister-F-PRED-NEG:PRED:Q

'But does the boy know that it is that: I am in fact really not your sister?' (Hhao in press:

Story of makaay)

The negative statement is emphasized by the adverb tsuwa. In this instance, any presuppositions by the other character is corrected to highlight this crucial fact that the audience already knows. Here too, tsuwa helps to repeat and emphasize the available knowledge that has been presented beforehand.

The function of tsuwa does not appear to overlap with mak. Mak and tsuwa can be used in the same clause, where the distinction between both functions is clearly expressed in (30). The hyena and Saramade have been eating their children in times of hunger, but Saramade has in fact been hiding her children who are still alive. When the hyena thinks she has heard the voice of these children, Saramade goes with hyena to the house they are hiding in and sings a welcoming song upon which the children remain quiet. Afterwards, in a rhetorical negative question, the hyena acknowledges the truth that the children are dead.

\begin{tabular}{|c|c|c|c|c|c|}
\hline $\begin{array}{l}\text { Baha } \\
\text { hyena.F }\end{array}$ & $\begin{array}{l}\text { i-ri } \\
\text { 3-CSEC }\end{array}$ & $\begin{array}{l}\text { ó', } \\
\text { say:3F }\end{array}$ & $\begin{array}{cc}\text { "A } & \text { mak } \\
\text { COP } & \text { mak }\end{array}$ & $\begin{array}{l}\text { tsuwá } \\
\text { TSUWA }\end{array}$ & $\begin{array}{l}\text { lóeéke." } \\
\text { truth:PRED:NEG:PRED:Q }\end{array}$ \\
\hline ta-na & $u_{1}$ & hoót. & & & \\
\hline IMPS-PST & T togethe & r live & & & \\
\hline
\end{tabular}

Mak is used in the 'set up' clause as the hyena asks if a situation is true. As mak has been used, we expect that the situation will in fact be false. Tsuwa acts as an intensifier, to confirm that the hyena is asking if the situation is really true. In this case, the two adverbs combined reflect that the hyena does not think the situation is entirely truthful as the intensifier asks if it is truly true, yet mak shows that the hyena expects it not to be so.

In imperative utterances, the function of tsuwa is to strengthen the order given.

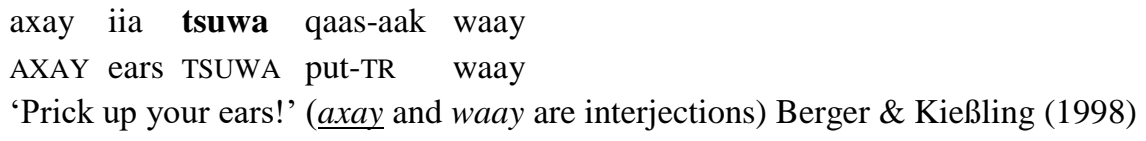

This sentence is commonly used to introduce a story, ordering the audience to be attentive. It is mostly used without tsuwa, but the addition of this adverb does nothing more than to strengthen the order.

In sum, tsuwa asserts the validity of what is expressed in a statement. Usually, the contents of such a statement has already been said. The adverb does not reflect the involvement of the subject; thus, it does not express stance. If a second statement from a different source is compared to an earlier statement, then tsuwa asserts the validity of it and can be translated as 'indeed'. In its emphatic and repeated assertion, tsuwa functions to take away any doubt there could be, but its use is not restricted to correcting expectations. When used in questions, the scope of the question is over tsuwa and the emphatic validity is what is put in question; the same is valid for leading questions 
with negation. In imperative sentences that are commands and not statements open to assertion, tsuwa strengthens the command given.

3.2 Tawó. Tawó (or tawo) and its shortened form too (or toó) are used to indicate 'nothing else.' This adverb occurs 74 times in our corpus. The adverb excludes potential alternatives and asserts that the action in the clause is the only one happening. For example, in (31) the rat instructs the cat to follow the dog strictly, and not to deviate from that.

$$
\begin{aligned}
& \text { seeaay u-na toó hhaawásh } \\
& \text { dog.M O.M-PST TAWO follow: } 2 \mathrm{SG} \\
& \text { 'The only thing you do is following the dog.' (Hhao in press: story of pete) }
\end{aligned}
$$

The adverb can express that the action of the clause is inevitable, there is no other option. In (32), the boy is warned not to show his arm since he would inevitably be killed.

$$
\begin{aligned}
& \text { Dawa mu laqaqamaar, asma kuú t-u too gaas. } \\
& \text { arm.M PROH:O.M show:NEG.IMP because 2SG.M IMPS-O.M TAWO kill } \\
& \text { 'Don't show your arm. because you will be killed.' (Mous et al. 2017: Story of Bibi } \\
& \text { Kuku) }
\end{aligned}
$$

The following sentences are from a story in which the calf warns its master that cannibals are going to kill him with poison. The calf advises him to just hold the beer calabash, to put it to its mouth, and not to drink from it. Even though drinking from it would be the logical next step, the calf tells him only to hold it. In this excerpt, tawo is used three times to indicate only to do the action of the verb, excluding the logical next step.

$$
\begin{aligned}
& \text { buura bar-kinga haniís, ka too kooma koón. } \\
& \text { beer.F COND-IMPS:O3:O.F:PRF give DEP:O3:O.F TAWO IMPFV have:2SG } \\
& \text { Kuú ka too qás bará afa Buura ga } \\
& \text { 2SG.M O3:O.F TAWO put:2SG side:CON mouth beer.F O3:O.F } \\
& \text { qaás bará afa, ga wah-an-a-ká, ga too máy. } \\
& \text { place:3M side:CON mouth O3:O.F drink-DUR-PRED-NEG O3:O.F TAWO leave:3M } \\
& \text { "When you are given beer, you just hold it. You just put it to the mouth." He puts the } \\
& \text { beer at the mouth; he does not drink; he just leaves it there.' (Mous et al. } 2017 \text { : Story of } \\
& \text { Gesso Duqang) }
\end{aligned}
$$

The use of tawó can exclude other expected aspects that are not just alternatives to the action of the clause. In the following example (34), tawó is used to indicate that there is talking even though the source of the talk is not visible.

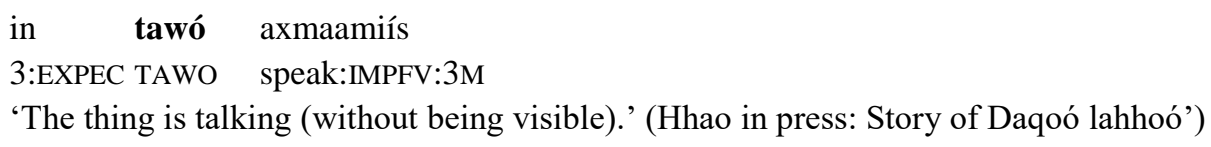


In the following passage, the first occurrence of too (35) indicates that the characters continued to herd despite the fact that the hare was not getting any profit from it. In other words, the characters were herding for no reason. Later in the story, the hare complains in despair that they are herding for nothing, for no use nor profit, which is expressed again by too (36). Tawo can be used to state that a certain action is in vain. The meaning of 'without doing anything else' has extended to 'without any result or reason.'

$$
\begin{aligned}
& \text { Kwa/aangw naanú gwa gaás, ta too hikwaá de’én. } \\
& \text { hare vegetables O3:O.M:PRF kill:3M:PST IMPS TAWO cattle:CON herd } \\
& \text { 'Hare ate vegetables (without milk), they still continued to herd.' (Mous et al. 2017: story } \\
& \text { of Kwa/aangw nee Baha) }
\end{aligned}
$$

$$
\begin{array}{lll}
\text { A } & \text { too } & \text { deaem-aán. } \\
1 / 2 & \text { TAWO } & \text { herd:IPFV-1PL }
\end{array}
$$

'We are herding for nothing.' (Mous et al. 2017: story of Kwa/aangw nee Baha)

The two meanings of 'nothing else' and 'for nothing' are both present in extract (37). Firstly, the hyena is running around in the lion's den and doing nothing else, and secondly, the running is in vain as it cannot escape when the lion returns.

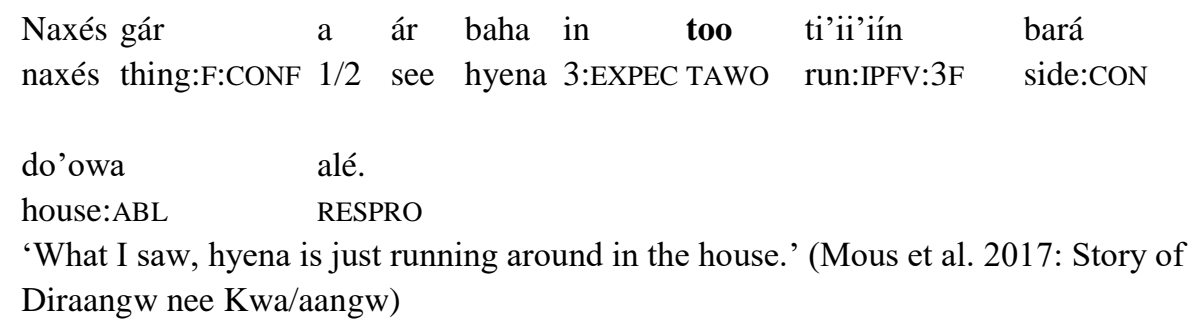

This second sense of tawo, expressing the fruitlessness of an action, is clear in the curse that Simbooya uses on the messengers that have drunk his milk but turn out to be incapable of carrying a message (38). The milk has been drunk to no avail, without the intended benefit: the birds who drunk the milk will not be able to travel.

$$
\begin{aligned}
& \text { Ilwaa-eé' i-na tawo wát, alók an tsarer'etká slaa'. } \\
& \text { milk.P-1SG.POSS O.P-PST TAWO drink:2SG ALÓK 1/2:EXPEC get.lost want:1SG } \\
& \text { 'You have drunk my milk for nothing; let you get lost (a curse).' (Nordbustad 1978b) }
\end{aligned}
$$

The adverb can render an action uncharacteristically short and effortless. In (39), a magic ring makes a two-storey-house instantly appear, fully built.

$$
\begin{aligned}
& \text { maraá qoroófa gi-na toó tléhh peete } \\
& \text { houses:CON storey O.3:O.P-PST TAWO build ring } \\
& \text { 'The ring built the house just like that (without effort, in no time, the house appeared } \\
& \text { magically)' (Hhao in press: Story of Pete) }
\end{aligned}
$$


The same unexpected suddenness is expressed by too in the following passage (40), where Lách is running for his life, then turns himself into a stone.

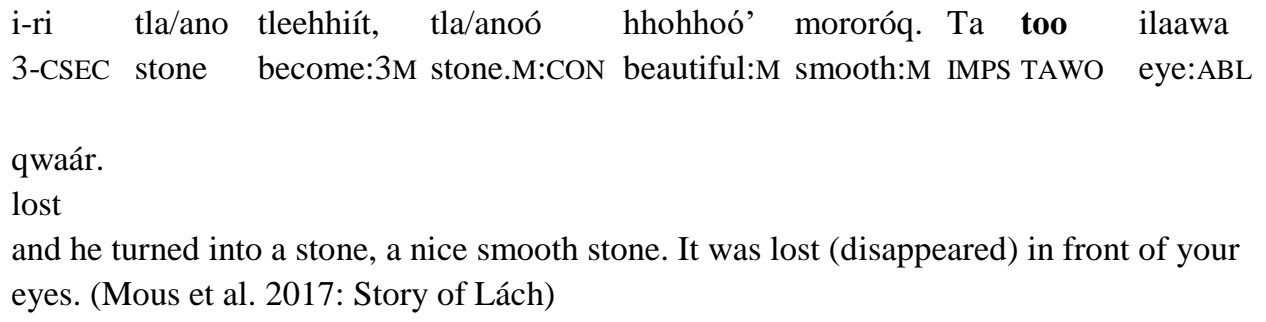

Tawo cannot only express suddenness but also immediateness. It is used in the following example (41) to express that at the moment the boy arrived, he started hitting the snake:
Kar too aangw i-wa
hardáh,
dayshimo g-u-na
muutatín
well TAWO before 3-BGND arrive:3M snake O3-O.M-PST hit:IPFV:3M
'As soon as he arrived, he hit the snake.' (Mous et al. 2017: Story of Daaqay 7)

Excluding other alternative actions can lead to the sense of intensity. In the following sentence (42), the hyena has been captured by the lion in his den and pleads for forgiveness. The verb contains reduplication which together with the adverb too, renders the pleas intensive.



The most likely origin of this adverb is nominal, as it can be used as a complement of a preposition. In (43), tawo means 'nothing' as the complement of the preposition ar 'with.'

$\begin{array}{llllllll}\text { Aamaá Tapó, laarí mas } & \text { mán } & \text { afátsiin } & \text { ar } & \text { tawo } \\ \text { mother:CON Tapo } & \text { today } & \text { Q:1/2:REAS } & \text { mouth:CON } & \text { scrape:2SG with } & \text { TAWO }\end{array}$

Lady Tapo why are eating your porridge with no sauce [lit. why are you scraping your mouth with nothing] (Nordbustad 1985)

Tawo is also nominal when used as a modifier of another noun. This is seen in examples such as heé toó /man:of nothing/ 'a useless man;' muruú tawo /things:of nothing/ 'worthless things;' gadiyeér tawo /work:of nothing/ 'staying quiet,' and doó tawo /house:of nothing/ 'a normal house' (as opposed to a multi-storey house).

In sum, tawo and its variants are used to indicate that only the action of the verb is what is happening. There are no alternative actions, no logical next step and none of the related additional conditions taking place, despite mitigating circumstances. Thus, the function of tawo is in a way opposite that of mak. While mak forecasts that there is something else to come that will crucially modify what is stated in the clause with mak; tawo indicates that the content of the clause is what is happening and nothing else; not even logical next steps. A second sense of tawo is to indicate that 
the action of the verb is without any result, outcome, benefit or aim. A third sense of tawo is to express that the action is without effort, suddenly, at once or intensively; restricting the action to its essence and focusing on the element of time.

3.3 Lak. The first of the three verbal adverbs relating to boundaries that we will compare our analysis of mak with, is lak. Lak occurs only 14 times in our corpus.

Unlike mak, lak does not require two components. The verbal adverb provides additional information on the degree of a descriptive clause and has two subtly distinct meanings depending on whether lak is used in relation to an action or a state. Examples (44) and (45) show lak being used to give additional information on the degree of an action, the most common use of lak in our corpus.

$$
\begin{aligned}
& \text { I-ri ó' Naambóoya án taa lak gáas nee múk } \\
& \text { 3-CSEC say:3F N 1SG IMPS:O1SG:PRF LAK kill:PST by people:M1:CON }
\end{aligned}
$$

doohúng.

house:2PL.POSS

She said: "Namboya, I was nearly killed by the people of your house!" (Berger \&

Kießling 1998)

$$
\begin{aligned}
& \text { Aa lak hamáar } \\
& \text { 3:PRF LAK ripen:3M } \\
& \text { 'It is almost ripe.' }
\end{aligned}
$$

In both examples, lak provides information that a situation could have happened, but in this case, did not. Although (45) may appear to refer to a state in the level of ripeness of a fruit, in this case $l a k$ refers to the action of the fruit ripening. The function of $l a k$ is to lessen the degree of an action that could have happened when speaking in the past or could happen when speaking in the present. Therefore, its meaning when referring to an action is comparable to 'almost.'

Lak has the same function when used in reference to a state, by lessening the degree to which that state mentioned is true. However, in this case, the meaning of lak changes to be closer in translation to 'partially.' This is shown in examples (46) and (47).

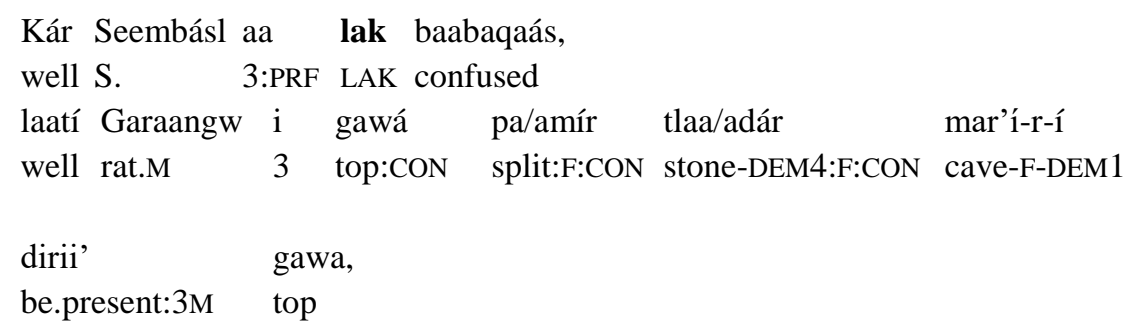

'Seembasl was a bit confused. Mouse was on top of the stone in the cave.' (Hhao in prep.: story of Seembásl)
Baba
garmaadá' niiná
g-u-ri
báy, "Kangwsíng ooang."
father boy.M-DEM4 small:M
O3-O.M-CSEC
say:M matter-DEM2 tell:VENT:TR 


\begin{tabular}{|c|c|}
\hline 10ó & niiná i-ri \\
\hline
\end{tabular}

aluuwo baaba xwaytsi gana tsaát, guri muúx, afterwards father rod.F O3-O.F-PST cut:3M O3-O.M-CSEC beat:3M 'Father told the younger boy: Tell me. The boy then refused, father cut a rod and beat him.' (Wada 1976: Story of Simbooya)

Example (46) shows the differentiation between using lak in a description of an action or of a state. In reference to a state, you cannot be 'almost' confused. However, as the function remains the same and the degree to which the state being described is lessened, in (46) Seembasl was not quite confused, meaning he was 'partially' confused. The same pattern is present in example (47), the boy showed partial refusal, which was enough of a stance for the father to then beat him.

From the examples discussed above, lak is similar to mak in that both adverbs can be generally summarised as linguistic tools for information management in discourse. Furthermore, there have been no examples in our corpus which suggest the two adverbs can be used together in one clause, as their placement in a sentence is similar. Despite the clear distinction in meaning described above, there are a few cases in which mak and lak may initially be seen as interchangeable. However, the completely separate functions of the two adverbs result in a subtle impact on the discourse in the choice of lak or mak. This is shown in example (48), in which lak appears to have the same features and translation as expected for mak.

\begin{tabular}{|c|c|c|c|c|c|c|c|c|}
\hline $\begin{array}{l}\text { Aluy } \\
\text { after }\end{array}$ & vards & $\begin{array}{l}\text { rka } \\
\mathrm{a}: \mathrm{F}: I N D F\end{array}$ & $\begin{array}{l}\text { gaa } \\
\text { O3-O. }\end{array}$ & $\begin{array}{ll} & \text { ila } \\
\text { PRF eye }\end{array}$ & $\begin{array}{l}\text { gaás, } \\
\text { kill:3M }\end{array}$ & $\begin{array}{l}\text { baha } \\
\text { hyena.F }\end{array}$ & $\begin{array}{l}\text { geéra } \\
\text { first }\end{array}$ & $\begin{array}{l}\mathrm{i} \\
3\end{array}$ \\
\hline $\begin{array}{l}\text { lak } \\
\text { LAK }\end{array}$ & $\begin{array}{l}\text { iiár } \\
\text { ear:F:CON }\end{array}$ & $\begin{array}{l}\text { qaasár } \\
\text { putting:F }\end{array}$ & $\mathrm{F}: \mathrm{CON}$ & $\begin{array}{l}\text { eér, } \\
\text { go:3F. }\end{array}$ & $\begin{array}{l}\text { gidaabá } \\
\text { because }\end{array}$ & $\begin{array}{l}\text { gaa } \\
\text { thing.F }\end{array}$ & $\begin{array}{l}\text { ngi } \\
\text { O3:O.F }\end{array}$ & axas \\
\hline $\begin{array}{l}\text { gaa } \\
\text { thing }\end{array}$ & $\begin{array}{l}\text { ila } \\
\text { eye }\end{array}$ & & nuút & $\begin{array}{l}\text { ar } \\
\text { ST INSTR }\end{array}$ & $\begin{array}{l}\text { tsataay. } \\
\text { knife }\end{array}$ & & & \\
\hline
\end{tabular}

'Then he hurt the hyena's eye, the hyena wanted to go to hear, in order to understand, but he had hurt the hyena's eye with a knife.' (Mous et al. 2017: Story of Kwa/aangw nee Baha)

There is a contrast in the sentence, as the hyena wants to go to listen, but his blinded eye makes it a difficult task for him. However, the choice of using lak rather than mak, means that the audience knows that the action described is lessened, rather than being an expectation that needs correcting. The hyena is on his way to listen, but he has not yet arrived. In this case, lak tells the audience that he is almost there, and gives a reason why he has not yet made it.

Example (48) can be written with mak replacing lak, but this would state to the audience that the hyena has not set off to listen, because even though he wants to, he has the contrasting difficulty of his injured eye. The choice of lak in this case means he has not yet arrived, or in other words, he has almost arrived. In the case of a boundary adverb, again our analysis shows that mak has a unique function of information management in the closed category of Iraqw verbal adverbs.

3.4 Ak. The adverb ak is not used often in the stories ( 22 times). It has been defined as expressing a higher degree, as the dictionary gives 'more, further' as its meaning. This meaning of 'higher 
degree' seems to be consistent when the adverb is used in relation to states. However, with adjectives, ak translates as 'very,' whether used predicatively or attributively.

$\begin{array}{lllll}\text { nee } & \text { dóo } & \text { ak } & \text { dihhóo' baráa } & \text { Suuleewo. } \\ \text { and } & \text { house:OF } & \text { AK } & \text { wealthy in } & \text { Suulee:PRED }\end{array}$

'And a very wealthy house among the Suulee.' (Berger \& Kießling 1998)

ya'ér ak-'ur
river:F:CON AK-big:F
'A very big river.'

The adverb is used with verbs of state in a similar fashion. In (51) it is used with the verb 'be angry' and in (52) in combination with ló 'wa 'truly, very,' showing two different expressions displaying a higher degree in this sentence.
Aluuwo gaa niwa nakál naxés xuraai i-na ak búhh then thing.F HITH-BGND near:3F naxés crow 3-PAST AK be.angry:3F 'When the thing came close, the crow became very angry' (Mous et al. 2017: Story 14)

$$
\begin{aligned}
& \text { Inooín tana ak ló'wa buúhh hi'itanooro sleeme wawatliaaká, } \\
& \text { they iMPS-PAST AK very be.angry travelling-F-BGND also go.home-PRED-NEG } \\
& \text { 'They became very angry and did not go home.' (Mous et al. } 2017 \text { story 13) }
\end{aligned}
$$

$A k$ occurs with other verbs of state in the corpus, such 'be afraid,' 'know,' 'be glued,' 'be wealthy' and 'be in quarantine'. Expressing higher degree presupposes gradability. But the adverb can also occur with action verbs and with those, $a k$ expresses intensity $(53,54)$ or duration $(55)$.

$$
\begin{array}{llll}
\text { iri } & \text { uú' } & \text { ak } & \text { 'alé. } \\
\text { 3-CSEC } & \text { scream:3M } & \text { AK } & \text { RES.PRO }
\end{array}
$$

'He was screaming louder.' (Berger \& Kießling 1998)

$\begin{array}{lllll}\text { Aluuwo Diraangw } & \text { i-na } & \text { mak } & \text { naanguút, } & \text { naxés adoo } \\ \text { then lion } & \text { 3-PST } & \text { MAK } & \text { move:3M } & \text { naxés manner.F }\end{array}$

datxa aa ak sí'.

now 3:PRF AK refuse:3F

'Then Lion tried to move, but this now completely did not work' (lit. refused). (Wada 1976: story 5)

$$
\begin{aligned}
& \text { Atén tsiní bara ak panáywa iwiiwitaán tsaraawo. } \\
& \text { 1PL better COND AK orphan:ABL stay:iMPRF:1PL two-PRED } \\
& \text { 'It is better if both us from now on remain orphans.' (Mous et al. 2017: story 5) }
\end{aligned}
$$

If a sentence with $a k$ also contains a standard against which the higher degree is expressed, then the result is a comparative construction. There are several ways in which such a comparative construction can be realised in Iraqw. One is with the verb waraahh 'to pass, surpass' in (56); another is with comparative preposition $t a$ 'than' (57). Yet another method is to express an area of 
comparison that is introduced with locative nouns, such as geeraá 'before' (58), or baraá 'in, at the side of' (27).

$\begin{array}{llll}\text { gár ak waraahh alók a } & \text { milá, } \\ \text { thing:F:CON AK } & \text { passing-F but }\end{array}$

'Which of them is the better thing?' Berger and Kießling 1998:

$\begin{array}{lllllll}\text { ayto'o-r-i } & \text { ka } & \text { ak } & \text { hho' } & \text { ta } & \text { ak } & \text { to-qa'-e } \\ \text { maize-F-DEM1 } & \text { O3:IMPS:O.F } & \text { ak } & \text { nice:F } & \text { than } & \text { AK } & \text { INDEP.F-DEM3-back }\end{array}$

'This maize is better than that maize there. ' Berger and Kießling 1998:

$\begin{array}{lllll}\text { kú } & \text { ak } & \text { tlákw geeraá } & \text { Tarár } & \text { hatlá } \\ \text { O3:IMPS:O.M } & \text { AK } & \text { be.bad:3M front:CON } & \text { datoga:CON } & \text { other }\end{array}$

'Is the worst of all the other Datoga.' (Berger and Kießling 1998:172)

When $a k$ is used in a negative sentence, the negation has scope over $a k$. Thus in (59), the negation of $a k$ results in 'not much.' $A k$ cannot intensify 'not entering' the sleeping corners; entering does occur - but only rarely. The same inability to intensify a negated sentence is true with adjectives in a nominal clause, as shown in (60).

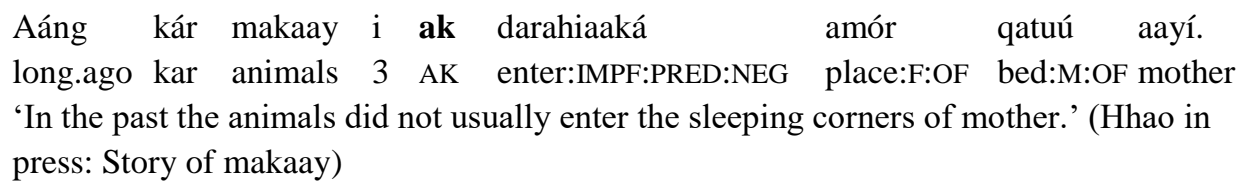

$$
\begin{array}{lllrl}
\text { Sawás } & \text { alaa ku } & \text { ak } & \text { ur-ee-ká. } \\
\text { sawás } & \text { but } & \text { O.3:IMPS:O.MAK } & \text { big-PRED-NEG }
\end{array}
$$

'And the Sawás were not very numerous.' (Berger and Kießling 1998)

In questions that contain $a k$, the higher degree is questioned. In (61), the hare and the leopard are in the middle of a fight about a house when the hare tries to make a compromise. His question about their fighting is marked by the questioning 'what?' clitic $m$ - in the clitic complex ma. Despite this, both know what they are fighting for, as they both claim possession of the house. What the hare wants to question is the continuation of this fight, and in the next sentence he proposes to share the house with the leopard.

$$
\begin{aligned}
& \text { Kwa/aangw i-na oó', hám dii-sing-e ma ak gilim-aán. } \\
& \text { hare 3-PST say:3M:PAST now place:F:DEM2-PRED Q-1/2 AK fight-1PL } \\
& \text { 'Hare said: "Why are we still fighting?"' (Mous et al. 2017: Story 2) }
\end{aligned}
$$

When $a k$ is used in a rhetorical question to oneself, the questioning of the degree of the action can be interpreted as doubt. Sentence (62) comes from a story in which a man asks himself whether it is wise to help the lion by taking a thorn from out of his foot. He mutters that he needs to think about it, and as he is inside whilst the lion is outside, perhaps it is safe enough to keep thinking. 

I-qo ak hara/akuúti?
O1SG-EMPH AK APPL-jump:3M:PRED:Q

'Is he really going to jump at me?' (Hhao in press: Story of Man and Lion)

The position of the verbal adverb $a k$ is before the verb but as with all elements that are restricted to the 'Before Verb' position, they can also appear after the verb with a resumptive alé, as we saw in (53) for $a k$. However, once outside the 'Before Verb' position, the phrase with alé can also occur in a sentence initial position. This is rare - however, the phrase ak'alé occurs three times in the initial position in the tales that Berger collected in the 1930s (Berger and Kießling 1998), (64,65) as well as in our corpus (63). This structure seems to have grammaticalised to become a discourse marker that introduces a particularly crucial and convincing consideration, 'moreover.' The verbal adverbs modify the entire clause, $(63,64)$. However, in this initial position ak'alé can modify the following noun (plus relative clause) as it does with 'people' in (65).
ak alé
ka-wa ur-ee
na/ay-dá-dá
oo
xooro.
AK RESPRO O.3:IMPS:O.F-BGND big-PRED boy-DEM4-DEM4 INDEP.CON.M nation 'what is even more important is that the boy is a boy of the nation.' (Mous 1993)

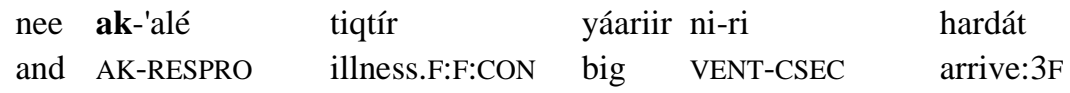

'And a severe disease came onto us, (Kießling and Berger 1998)

$\begin{array}{lllll}\text { ak'alé } & \text { múk } & \text { kángw } & \text { adoorí } & \text { gu } \\ \text { AK-RESPRO } & \text { people:M1:CON } & \text { matter:M:CON } & \text { manner:F:DEM1 } & \text { O.3-O.M }\end{array}$

alhooreemaamíis

thinking:IPFV:3M

'Especially those people who always think of these things (violence and stealing),'

(Berger \& Kießling 1998)

In sum, the adverb $a k$ indicates that a gradable state of affairs expressed by the predicate of the clause (verb, adjective) has a higher level. This becomes 'very' for qualities of states and 'intensely' or 'for a longer period' for actions and iterations of punctual verbs. The adverb $a k$ is used in various comparison constructions in which the comparison interpretation comes either from the verb 'to surpass' or from the expression of a referent for comparison. Negation and questioning scope over $a k$ due to its syntactic function of verbal adverb. The combination ak'alé when used sentence initially indicates the entire clause is a higher level in a discourse perspective, indicating that the clause is a more salient instantiation of the preceding one.

3.5 Algé. Algé (or alge) is not used very often in the stories; occurring only 12 times within our corpus. Its meaning appears similar to lak, as the adverb requires one component and is concerned with the degree of actions or states.

In most cases, algé appear to have the function of stating an action or state is only partially present. Whereas lak lessens the degree of an action to describe what 'almost' happened, algé instead tells us that a state is present to some degree, or 'rather.' This can be seen in examples (66) and (67) below. 
(66)

\begin{tabular}{llllll} 
dír & \multicolumn{1}{c}{ bihhaá } & \multicolumn{1}{c}{ hhalaangooká, } & ku & algé & saáw. \\
place:F:CON & side:P:CON & well:P-PRED-DEM1 & O3:IMPS:O.M & ALGE & far \\
Kár & g-u-na & al/aáy & & & \\
well & O3-O.M-PST & deceive:3M & & &
\end{tabular}

'at the side of this well, he was rather far.' He deceived them.' (Hhao in press: Story of Quye)

\begin{tabular}{|c|c|c|c|c|c|}
\hline gawá & xa'ano & niiná & oo & algée & wananáa' \\
\hline top:P:CON & tree.M & small:M & INDEP.CON.M & ALGE & fat:DEM 4 \\
\hline
\end{tabular}

In (66), the character is described as being 'rather' far away by being positioned at that side of the well. Being at this distance means that the character is hidden, and he has been able to deceive the others. The distinction between algé and lak can be summarised by the difference in meaning that would occur in the choice between these two adverbs in an actual example. If this sentence had been written with lak, the audience would interpret this as the character was not quite far enough away at that side of the well, and the character would be unable to deceive the others at this distance. Similarly, algé is used in (67) to refer to the fact the object on top of the small tree is 'rather' fat. Algé has the function of highlighting a quality that exists to some degree, whereas lak highlights a quality that is lacking to some degree.

In constructed examples, it was tested with first language speakers of Iraqw whether algé could be used with several words, including: gumbalalahh (round), basa (south), kiis (open), afahhoo' (boasting), naaqoo (secretly), and gwaa' (to die), which could only be possible if the object in question was an instrument and not a human. A tool could be 'rather' dead if it did not work to some degree, but a person could not. This test shows the scope of using algé, as the adverb can be applied to reflect the degree of a state that cannot explicitly be measured.

Within our corpus there appears to be no occurrence of mak and algé used in the same sentence. However, due to the minimal usage of algé in the stories this is not to say that the two adverbs cannot be used together, as the meanings and functions of both appear to be distinct.

\section{Conclusion}

After a careful analysis, we concluded that mak signals that there will be an upcoming contrast in the following clause(s). This contrast opposes either the present statement or what is implied to happen next.

In comparison to other adverbs which were predicted to have a similar function to mak: first the boundary adverbs of tawo and tsuwa, and second the expectation management adverbs of $l a k$, ak and alge, we have found that mak does not fit into either group. Functionally, all 5 of the comparison adverbs are organising the clause level. The boundary adverbs tawo and tsuwa both refer to semantics out of the clause they are placed in by evaluating the purposelessness of solely concentrating on one act (tawo) and understanding the value of truth (tsuwa). These adverbs therefore refer to larger knowledge of the world - not just that of the story. The two expectation adverbs are semantically internal to the clause they organise, as they adjust the descriptions within the world they are placed in. On the other hand, mak is the only adverb in this set that organises the information above the clause level, at the discourse level. Mak relates elements of the story and is 
used as an optional information management tool that indicates there is more to be said about the topic described in the clause in which mak is placed within.

We showed that mak is rarely used together with negation because it is pragmatically odd. This is similar to tawo which is not used with negation since it is pragmatically odd to use negation together with exclusion of other options; and likewise for the combination of questioning and tawo. Using questioning in sentences with tsuwa, renders the asserted value of tsuwa doubt. When negation is used with $a k$, it is the higher degree that is negated and likewise questioning a sentence with $a k$ questions the higher degree. We have no examples of $l a k$ in negated or questioned sentences. Negation and questioning is pragmatically odd with some of these adverbs (mak, tawo), and with others the questioning and negation takes the adverb as affected variable ( $a k, t s u w a)$. Negation and questioning is always marked on the verb or the inflectional particle in Iraqw which is also the exclusive domain of these verbal adverbs (Mous and Qorro 2010). Hence, questioning and negation can take these adverbs in their scope.

This analysis has provided evidence for mak to be re-defined as an information management adverb with the function of indicating an upcoming contrast. A closer look into cases such as these allows us further understanding in the possible functions in languages across the globe and gives us greater knowledge on the possible styles in storytelling from wider pool of data.

\begin{tabular}{|c|c|c|c|}
\hline \multicolumn{4}{|c|}{ Abbreviations } \\
\hline \multicolumn{4}{|c|}{$\begin{array}{l}\text { Abbreviations } \\
1 / 2 \quad \text { first or second person }\end{array}$} \\
\hline $1,2,3$ & first, second, third person & IMP & imperative \\
\hline $\mathrm{CON}$ & construct case & INDF & indefinite \\
\hline COND & conditional & INSTR & instrumental \\
\hline COP & copula & M & masculine \\
\hline CSEC & consecutive & M1 & subgroup of masculine \\
\hline DEM & demonstrative (numbers refer to & $\mathrm{P}$ & plural gender \\
\hline \multicolumn{2}{|c|}{ degree of distance) } & NEG & negative \\
\hline DEP & dependent (clause) & $\mathrm{O}$ & object \\
\hline DIR & directional & PRF & perfect \\
\hline DUR & durative & PL & plural \\
\hline ЕMPH & emphasis & POSS & possessive \\
\hline EXPEC & expectational & PRED & predicative \\
\hline $\mathrm{F}$ & feminine & $\mathrm{PROH}$ & prohibitive \\
\hline F1 & subgroup of feminine & REAS & reason \\
\hline FRQ & frequentative & SG & singular \\
\hline HAB & habitual & VENT & ventive \\
\hline
\end{tabular}

\section{References}

Berger, Paul and Roland Kießling (eds.) 1998. Iraqw Texts. Cologne: Rüdiger Köppe. Elders, Stefan and Maarten Mous 1991. The adverbial qo in Iraqw.” In Ägypten im afroorientalischen Kontext: Aufsätze zur Archäologie, Geschichte und Sprache eines unbegrenzten Raumes, ed. by Ulrike Claudi and Daniela Mendel (Afrikanische Arbeitspapiere, special issue 1991), 125-138.

Fraser, Bruce. 1996. Pragmatic markers. Pragmatics, 6, 167-190.

Hhao, Basilia (ed.) in press. Ama Irmí na hadithi nyingine [Ama Irmi and other stories, 18 Iraqw 
stories with Swahili translation].

Izutsu, Mitsuko Narita. 2008. Contrast, concessive and corrective: toward a comprehensive study of opposition relations. Journal of pragmatics 40, 646-675.

Johnson, Frederick 1939. A Standard English-Swahili Dictionary. Oxford: Oxford University Press.

Mous, Maarten 1993. A grammar of Iraqw (Cushitic Language Studies, 9.) Hamburg: Helmut Buske.

Mous, Maarten 2018. Phasal Polar expressions in Iraqw and Mbugu : a category? Paper presented at International Conference on The Expression of Phasal Polarity in sub-Saharan African languages, Hamburg 2-3 February 2018.

Mous, Maarten \& Martha Qorro 2008. The Evidential Adverb hhóo in Iraqw. In Semito-Hamitic Festschrift for A.B. Dolgopolsky and H. Jungraithmayr, ed. by Gábor Takács (ed.). 223230. Berlin: Dietrich Reimer.

Mous, Maarten, Martha Qorro 2010. The syntactic function of a scope marking suffix in Iraqw. Journal of African Languages and Linguistics 31: 47-78

Mous, Maarten, Martha Qorro and Roland Kießling 2002. An Iraqw - English Dictionary (Cushitic Language Studies,15) Cologne: Rüdiger Köppe.

Mous, Maarten, Safari Sanka and Basilisa Hhao (eds) 2017. ${ }^{2}$ Geesoó Duqangw na hadithi nyingine za Kiiraqw. [Geeso Duqangw and other Iraqw stories]. (Mother Tongue Series, 3.) Leiden: Leiden University, Department of African Linguistics.

Mous, Maarten, Amy Catling and Sandra Bleeker 2018. Iraqw Oral Literature. In Daniela Merolla (ed.), Verba Africana: African Languages and Oral Literatures http://www.verbafricana.org/iraqw/ Paris: INALCO \& Leiden University.

Myhill, John and Zhiqun Xing. 1996. Towards an operational definition of discourse contrast. Studies in Language 20:2. 303-360.

Nordbustad, Frøydis. 1978a. Tiitár Iraqw. Hadithi za Wairaqw. (Iraqw Folklore Series, 3.) Mbulu: Christian Literature Centre.

Nordbustad, Frøydis. 1978b. Símbooya. Hadithi ya Simbooya. (Iraqw Folklore Series, 6.) Mbulu: Christian Literature Centre.

Nordbustad, Frøydis. 1985. Lách: Tiitár Ookwalángw nee Hhaawú. Hadithi ya Sungura na Fisi. An Iraqw folktale. (Iraqw Reader, 1.) Mbulu: Evangelical Lutheran Church

Stalnaker, Robert. 1973. Presuppositions. Journal of philosophical logic 2, 447-457.

Tseronis, Assimakis 2009. Qualifying Standpoints Stance adverbs as a presentational device for managing the burden of proof. PhD Leiden University. Utrecht: LOT.

Tosco, Mauro 2010. Why contrast matters. Information structure in Gawwada (East Cushitic). In: The expression of Information structure. Editors Ines Fiedler and Anne Schwarz.

Wada, Shohei. 1976. Hadithi za mapokeo ya Wairaqw (Iraqw folktales in Tanzania). (African Languages and Ethnography, 5.) Tokyo: Institute for the Study of Languages and Cultures of Asia and Africa.

Amy Catling <amcatling@gmail.com>

Leiden University,

The Netherlands 
Maarten Mous <m.mous@hum.leidenuniv.nl>

Leiden University,

The Netherlands 